\title{
PENGARUH RELAKSASI OTOT PROGRESIF TERHADAP PENURUNAN TEKANAN DARAH PADA LANSIA DENGAN HIPERTENSI DI DUSUN IV TANJUNG ANOM MEDAN TAHUN 2018
}

\author{
* Indra Hizkia P, S.Kep, Ns, M.Kep \\ ** Ance Siallagan, S.Kep, Ns, M.Kep \\ *** Mega Tresna Hulu, S.Kep
}

Staff Pengajat STIKes Santa Elisabeth Medan

\begin{abstract}
ABSTRAK
Latar Belakang : Hipertensi pada lansia ditandai dengan terjadinya peningkatan tekanan darah sistolik dan diastolik yaitu $\geq 140 / 90 \mathrm{mmHg}$ secara menetap dan sering terjadi pada lansia yang berusia $\geq 55$ tahun. Relaksasi Otot Progresif merupakan salah satu teknik yang dapat merelaksasikan otot tegang dan menciptakan perasaan yang relaks sehingga dapat menurunkan tekanan darah.

Tujuan : Penelitian ini bertujuan untuk mengetahui pengaruh relaksasi otot progresif terhadap penurunan tekanan darah pada lansia dengan hipertensi di Dusun IV Tanjung Anom Medan Tahun 2018.

Metode : Desain penelitian yang digunakan yaitu one group pretest and post test design dengan metode purposive sampling yaitu sebanyak 28 responden lansia yang berada di Dusun IV Tanjung Anom Medan. Instrumen yang digunakan dalam pengambilan data yaitu SOP, lembar observasi, stetoskop, sphygmomanometer.

Hasil : Analisa data menunjukkan hasil tekanan darah pre intervensi sebagian besar pada hipertensi derajat 1 sebanyak 16 orang $(57,1 \%)$ dan post intervensi sebagian besar pada prehipertensi sebanyak 13 orang (46,4\%). Hasil uji statistik Wilcoxon Sign Rank Test, menunjukkan nilai $\mathrm{p}=0,000(\mathrm{p}<0,05)$ artinya adanya pengaruh relaksasi otot progresif terhadap penurunan tekanan darah pada lansia dengan hipertensi di Dusun IV Tanjung Anom Medan Tahun 2018.
\end{abstract}

Kesimpulan : Hasil penelitian ini diharapkan lansia mampu menerapkan relaksasi otot progresif ini secara rutin.

\section{Kata Kunci : Hipertensi}

\section{ABSTRACT}

Background: Hypertension in the elderly is characterized by an increase in systolic and diastolic blood pressure of $\geq 140 / 90 \mathrm{mmHg}$ persistently and often occurs in \pm 55 years old elderly. Progressive Muscle Relaxation is one technique that can relax muscle tension and create a relaxed feeling that can lower blood pressure.

Goals : This study aims to determine the effect of progressive muscle relaxation on blood pressure decrease in elderly with hypertension in Dusun IV Tanjung Anom Medan Year 2018.

Methods : The design used design is one group pretest and post test design with purposive sampling method that is 28 respondents elderly who are in Dusun IV Tanjung Anom Medan. The Instruments used for taking data were SOP, observation sheet, stethoscope, sphygmomanometer

Result : Data analysis showed the result of pre intervention blood pressure mostly on 1st degree of hypertension 16 people $(57,1 \%)$ and post intervention mostly on 
prehypertension were 13 people (46,4\%). The result of Wilcoxon Sign Rank Test statistic shows that $p=0,000(p<0,05)$ means the effect of progressive muscle relaxation on blood pressure drop in elderly with hypertension in Dusun IV Tanjung Anom Medan Year 2018.

Conclutions : The result of this study is expected elderly able to apply this progressive muscle relaxation routinely.

Keywords: Blood Pressure, Progressive Muscle Relaxation, Elderly, Hypertension

\section{PENDAHULUAN}

Lanjut usia suatu proses yang tidak dapat dihindari, berjalan terus menerus dan berkesinambungan dan menyebabkan perubahan anatomis, fisiologis pada tubuh secara keseluruhan. Lanjut usia ditandai dengan umur harapan hidup yang semakin meningkat dari tahun ke tahun (Maryam, 2008). Menurut WHO batasan lanjut usia yaitu 60-74 tahun, lanjut usia tua usia 75-90 tahun, dan usia sangat tua usia > 90 tahun (Padila, 2013). Dep.Kes.RI membagikan kelompok lanjut usia menjadi kelompok menjelang usia lanjut usia 45-54 tahun, kelompok usia lanjut 55-64 tahun dan kelompokkelompok usia lanjut > 65 tahun (Aspiani, 2014). Di seluruh jumlah orang lanjut usia di perkirakan ada 500 juta dengan usia rata-ratas 60 tahun dan diperkirakan pada tahun 2025 akan mencapai 1,2 miliyar. Di negara maju seperti Amerika serikat pertambahan orang lanjut usia diperkirakan 1.000 orang per hari tahun 1985 dan diperkirakan $50 \%$ dari penduduk berusia diatas 50 tahun (Padila, 2013).

Pertambahan usia akan menimbulkan perubahan-perubahan pada struktur dan fisiologis dari berbagai sel/jaringan/organ dan sistem yang ada pada tubuh manusia (Mubarak, 2009). Walaupun demikian harus diakui bahwa ada berbagai penyakit yang sering dialamai oleh lanjut usia. Manusia secara lambat dan progresif akan kehilangan daya tahan terhadap infeksi dan akan menempuh berbagai macam penyakit degenerasi seperti hipertensi, arteriosklerosis, diabetes melitus dan kanker (Nugroho, 2012). Salah satu gangguan kesehatan yang dialamai oleh lansia yaitu hipertensi dimana dinding pembuluh darah mengalami penebalan sehingga menjadi kaku. Diameter rongga darah mengecil atau menyempit sehingga aliran darah tidak selancar pada orang yang berusia muda. Hal ini menyebabkan elastisitas (kelenturan) pembuluh darah berkurang dan menyebabkan pengerasan pembuluh darah (arteriosklerosis) (Santoso, 2009).

Pada hipertensi keluhan yang biasa dialami yaitu nyeri kepala oksipitalis (yang terjadi akibat peningkatan tekanan intrakranial), perasaan pusing, keletihan, binggung yang disebabkan oleh penurunan perfusi darah akibat vasokontriksi pembuluh darah (Kowalak, 2011). Relaksasi otot progresif merupakan salah satu terapi modalitas yang dapat mengurangi hipertensi. Dari keluhan tersebut terapi relaksasi merupakan tindakan non farmakologi yang dapat menurunkan kadar emosional dan menyebabkan keadaan parasimpatis yang dominasi melalui penenang korteks serebral serta memiliki efek yang luas diberbagai bidang kelompok penyakit (Doris, 2007). Teknik khusus ini didesain untuk membantu meredakan ketegangan otot yang terjadi ketika sadar. Membantu bagi bermacam-macam masalah yang terkait dengan stres termasuk amarah, insomnia, pusing dan hipertensi yang dapat menciptakan suatu keadaan emosional yang tidak menyenangkan (Mckay, 2005). 
Teknik relaksasi ini pertama kali dikembangkan oleh Edmund Jacobsen, yang percaya bahwa seseorang dapat diubah menjadi relaks pada otot-ototnya. Sekaligus juga latihan ini mengurangi reaksi emosi yang bergelora, baik pada sistem saraf pusat maupun pada sistem saraf otonom. Latihan ini dapat meningkatkan perasaan segar dan sehat. Teknik ini merupakan teknik yang lebih pendek, lebih sederhana dan lebih mudah untuk dilakukan (Gunarsa, 2008).

Survei data awal yang dilakukan pada Bulan Desember 2017 di Dusun IV Tanjung Anom didapatkan jumlah lansia yang berusia $\geq 55$ tahun yang mengalami hipertensi sebanyak 83 orang. Berdasarkan latar belakang diatas maka peneliti tertarik untuk meneliti mengenai pengaruh relaksasi otot progresif terhadap penurunan tekanan darah pada lansia dengan hipertensi di Dusun IV Tanjung Anom.

\section{METODE PENELITIAN}

Penelitian ini menggunakan penelitian Pre-Eksperimental dengan menggunakan rancangan (One Group Pretes Posttest Design) tanpa ada kelompok pembanding (kontrol). Rancangan ini paling tidak sudah dilakukan observasi pertama (pretest) yang memungkinkan menguji perubahan-perubahan yang terjadi setelah adanya eksperimen (program) (Notoadmojo, 2012). Sampel dalam penelitian ini sebanyak 28 lanjut usia di Dusun IV Tanjung Anom Medan. Pengumpulan data dilakukan dengan melakukan pengukuran tekanan darah menggunakan stetoskop dan sphygmomanometer. Analisa data menggunakan uji statistic Wilcoxon.
HASIL PENELITIAN

\subsubsection{Karakteristik Responden}

\section{Tabel 5.1 Distribusi Frekuensi \\ Karakteristik Responden \\ Berdasarkan Klien \\ Hipertensi di Dusun IV \\ Tanjung Anom Medan \\ Tahun $2018(n=28)$}

\begin{tabular}{|c|c|c|}
\hline Karakteristik & f & $\%$ \\
\hline \multicolumn{3}{|l|}{ Jenis kelamin } \\
\hline Laki-laki & 7 & 78,6 \\
\hline Perempuan & 21 & 21,4 \\
\hline Total & 28 & 100 \\
\hline \multicolumn{3}{|l|}{ Umur } \\
\hline$\geq 55-64$ tahun & 22 & 78,6 \\
\hline$>65$ tahun & 6 & 21,4 \\
\hline Total & 28 & 100 \\
\hline \multicolumn{3}{|l|}{ Agama } \\
\hline Protestan & 6 & 21,4 \\
\hline Islam & 21 & 75 \\
\hline Hindu & 1 & 3,6 \\
\hline Total & 28 & 100 \\
\hline \multicolumn{3}{|l|}{ Suku } \\
\hline Karo & 20 & 71,4 \\
\hline Jawa & 4 & 14,3 \\
\hline Tamil & 1 & 3,6 \\
\hline Batak toba & 2 & 7,1 \\
\hline Mandailing & 1 & 3,6 \\
\hline Total & 28 & 100 \\
\hline \multicolumn{3}{|l|}{ Pekerjaan } \\
\hline Wiraswasta & 8 & 28,6 \\
\hline Petani & 11 & 39,3 \\
\hline Dll & 9 & 32,1 \\
\hline Total & 28 & 100 \\
\hline \multicolumn{3}{|l|}{ Pendidikan } \\
\hline Terakhir & 17 & 60,7 \\
\hline SD & 4 & 14,3 \\
\hline SMP & 7 & 25 \\
\hline \multicolumn{3}{|l|}{ SMA } \\
\hline Total & 28 & 100 \\
\hline \multicolumn{3}{|l|}{ Status } \\
\hline Menikah & 19 & 67,9 \\
\hline Janda/duda & 9 & 32,1 \\
\hline Total & 28 & 100 \\
\hline
\end{tabular}


21 orang $(75 \%)$ dan laki-laki 7 orang (25\%). Responden berumur $\geq 55-64$ tahun sebanyak 22 orang $(78,6 \%)$ dan berumur > 65 tahun sebanyak 6 orang $(21,4 \%)$. Responden beragama kristen protestan sebanyak 6 orang $(21,4 \%)$, islam 21 orang $(75 \%)$, hindu 1 orang $(3,6 \%)$. Responden yang bersuku karo 20 orang $(71,4 \%)$, suku jawa 4 orang $(14,3 \%)$, suku tamil 1 orang $(3,6 \%)$, suku batak toba 2 orang $(7,1 \%)$ dan bersuku mandailing 1 orang $(3,6 \%)$. Responden bekerja sebagai wiraswasta 8 orang $(28,6 \%)$, petani 11 orang $(14,3 \%)$, dll sebanyak 9 orang $(32,1 \%)$. Responden yang berpendidikan terakhir SD sebanyak 17 orang $(60,7 \%)$, yang SMP sebanyak 4 orang $(14,3 \%)$ dan yang SMA 7 orang (25\%). Responden dengan status menikah sebanyak 19 orang $(67,9 \%)$ dan janda/duda 9 orang $(32,1 \%)$

\subsubsection{Tekanan darah pada lansia dengan hipertensi pre intervensi relaksasi otot progresif di Dusun IV Tanjung Anom Medan Tahun 2018}

Tabel 5.2 Tekanan darah pada lansia dengan hipertensi pre intervensirelaksasi otot progresif di Dusun IV Tanjung Anom Medan Tahun $2018(n=28)$

\begin{tabular}{ccr}
\hline $\begin{array}{c}\text { Klasifikasi } \\
\text { Tekanan Darah }\end{array}$ & F & \% \\
\hline Hipertensitahap 1 & 16 & 57,1 \\
Hipertensitahap 2 & 12 & 42,9 \\
\hline Total & $\mathbf{2 8}$ & $\mathbf{1 0 0}$ \\
\hline Berdasarkan & tabel & 5.2 \\
diperoleh bahwa & pada & sebelum \\
intervensi didapatkan & responden yang \\
memiliki hipertensi tahap 1 sebanyak 16 \\
orang (57,1\%) dan responden hipertensi \\
tahap 2 sebanyak 12 orang (42,9\%).
\end{tabular}

\subsubsection{Tekanan darah pada lansia dengan hipertensi post intervensi relaksasi otot progresif di Dusun IV Tanjung Anom Medan Tahun 2018}

Tabel 5.3 Tekanan darah pada lansia dengan hipertensi post intervensirelaksasi otot progresif di Dusun IV Tanjung Anom Medan Tahun $2018(n=28)$

\begin{tabular}{ccc}
\hline $\begin{array}{c}\text { Klasifikasi Tekanan } \\
\text { Darah }\end{array}$ & $\mathbf{F}$ & $\mathbf{\%}$ \\
\hline Normal & 3 & 10,7 \\
Prehipertensi & 13 & 46,4 \\
Hipertensi Tahap 1 & 10 & 35,7 \\
Hipertensi Tahap 2 & 2 & 7,2 \\
\hline Total & $\mathbf{2 8}$ & $\mathbf{1 0 0}$ \\
\hline Berdasarkan & tabel & 5.3
\end{tabular}

diperoleh bahwa pada setelah intervensi didapatkan hasil bahwa respondden dengan tekanan darah normal sebanyak 3 orang $(10,7 \%)$, prehipertensi sebanyak 13 orang $(46,4 \%)$, hipertensi tahap 1 sebanyak 10 orang $(35,7 \%)$, hipertensi tahap 2 sebanyak 2 orang $(7,2 \%)$.

\subsubsection{Pengaruh relaksasi otot progresif terhadap penurunan tekanan darah pada lansia dengan hipertensi di Dusun IV Tanjung Anom Medan Tahun 2018}

Di peroleh hasil bahwa ada perubahan tekanan darah responden sebelum dan setelah pemberian relaksasi otot progresif. Data pada penelitian ini tidak berdistribusi normal dan variabel berskala ordinal maka uji alternatif dalam penelitian ini menggunakan uji Wilcoxon Sign Rank Test. Berdasarkan hasil uji statistic wilcoxon sign rank test, diperoleh $p$ value $=0,000(p<0,05)$. Hasil tersebut menunjukkan bahwa ada pengaruh yang bermakna antara relaksasi otot progresif terhadap penurunan tekanan darah pada lansia 
dengan hipertensi di Tanjung Anom Medan Tahun 2018.

\section{PEMBAHASAN}

\subsubsection{Tekanan Darah Pada Lansia Dengan Hipertensi pre intervensi Relaksasi Otot Progresif Di Dusun IV Tanjung Anom Medan Tahun 2018}

Adapun Tekanan Darah Pada Lansia Dengan Hipertensi pre intervensi Relaksasi Otot Progresif Di Dusun IV Tanjung Anom Medan Tahun 2018 di dapat dari 28 responden menunjukkan bahwa yang mengalami tekanan darah tinggi sebelum diberikan intervensi relaksasi otot progresif terhadap lansia dengan hipertensi derajat 2 (42,9\%), hipertensi derajat $1(57,1 \%)$.

Sesuai dengan teori Dalimarth (2008), dimana wanita pasca menopause (sekitar 45 tahun) berisiko tinggi untuk mengalami hipertensi dibandingkan lakilaki. Didukung oleh teori Maryam (2008), begitu juga dengan usia salah satu faktor resiko, semakin tinggi usia seseorang elastisitas dinding aorta menurun, katup jantung menebal dan menjadi kaku, kemampuan jantung memompa darah menurun (menurunnya kontraksi dan volume), elastisitas pembuluh darah menurun, serta meningkatnya resistensi pembuluh darah perifer sehingga tekanan darah meningkat.

HerwatidanWiwi(2011),

menyatakanbahwafaktor gizi sangat berhubungan dengan terjadinya hipertensi melalui beberapa mekanisme. Arterosklerosis merupakan penyebab utama terjadinya hipertensi yang berhubungan dengan diet seseorang. Gaya hidup yang tidak sehat, obesitas (hiperlipidemia), kurang berolahraga, konsumsi garam berlebih dan kurang asupan serat merupakan pemicu terjadi hipertensi. Didukung oleh Kemenkes (2014), faktor resiko terjadinya hipertensi adalah umur, jenis kelamin, riwayat keluarga, genetik (faktor resiko yang tidak dapat diubah/dikontrol), kebiasaan merokok, konsumsi garam, konsumsi lemak jenuh, kebiasaan konsumsi minum-minuman beralkohol, obesitas, kurang aktifitas fisik, stres, penggunaan estrogen.

Data demografi merupakan salah satu faktor yang mempengaruhi peningkatan tekanan darah pada lansia. Dalam penelitian ini didapatkan lebih banyak jenis kelamin perempuan dari pada laki-laki. Dimana wanita lebih beresiko mengalami hipertensi dikarenakan setelah umur $\geq 55$ tahun yang telah mengalami menopause mengalami peenurunan hormon pada lansia tersebut. Serta usia yang semakin bertambah dapat menurunkan ke elastisitas pembuluh darah sehingga dapat meningkatkan tekanan darah. Selama proses penelitian dari hasil wawancara dan observasi yang dilakukan kepada responden, didapatkan bahwa responden masih berada pada sebagian besar dikategori hipertensi derajat 1 dan hipertensi derajat 2 . Hal ini terjadi dikarenakan pola hidup yang kurang baik seperti pola makanan (konsumsi garam atau kafein yang tinggi, kurangnya aktivitas fisik), kebiasaan merokok, konsumsi lemak jenuh, usia $\geq 55$ tahun, dan adanya riwayat keluarga yang mengalami hipertensi

\subsubsection{Tekanan Darah Pada Lansia Dengan Hipertensi post intervensi Relaksasi Otot Progresif Di Dusun IV Tanjung Anom Medan Tahun 2018}

Adapun tekanan darah pada lansia dengan hipertensi pre intervensi relaksasi otot progresif di Dusun IV Tanjung Anom Medan Tahun 2018. didapat dari 28 responden menunjukkan bahwa yang mengalami tekanan darah normal sebanyak $(10,7 \%)$, prehipertensi sebanyak $(46,4 \%)$, hipertensi tahap 1 sebanyak $(35,7 \%)$ dan hipertensi tahap 2 
sebanyak $(7,1 \%)$. Dalam penelitian ini didapatkan terjadi penurunan tekanan darah setelah dilakukan relaksasi otot progresif. Yang mengalami tekanan darah normal sebanyak 3 orang, prehipertensi sebanyak 13 orang, hipertensi tahap 1 sebanyak 10 orang dan hipertensi tahap 2 sebanyak 2 orang.

Khairani (2015), menunjukkan bahwa setelah dilakukan relaksasi otot progresif di dapatkan hasil 9 orang responden hipertensi ringan, 6 orang responden hipertensi sedang, dan tidak ada lagi responden yang mengalami hipertensi berat. Hal ini dikarenakan relaksasi otot progresif bekerja menurunkan resistensi perifer dan menaikkan elastisitas pembuluh darah. Otot-otot dan peredaran darah akan lebih sempurna dalam mengambil dan mengedarkan oksigen serta relaksasi otot progresif dapat bersifat vasodilator yang efeknya memperlebar pembuluh darah dan dapat menurunkan tekanan darah.

Sesuai dengan teori Setyoadi \& Kushariadi (2011) yang menyatakan bahwa relaksasi otot progresif dapat menurunkan ketegangan otot, kecemasan, nyeri leher dan punggung, tekanan darah tinggi, frekuensi jantung, laju metabolik, engurangi distrimia jantung, kebutuhan oksigen, meningkatkan gelombang alfa otak yang terjadi ketika klien sadar dan tidak memfokuskan perhatian serta relaks, mengatasi kelelahan, spasme otot.

Pada penelitian ini ditemukan adanya penurunan tekanan darah pada lansia. Penurunan tekanan darah ini terjadi dikarenakan pada saat kondisi tubuh yang seseoranga yang merasakan relaksasi berada dalam keadaan sadar namun rileks, tenang, istirahat pikiran, otot-otot rileks, mata tertutup dan pernapasan teratur maka keadaan inilah yang dapat menurunkan tekanan darah pada lansia. Sehingga lansia lansia yang serius dalam melakukan relaksasi otot progresif mengalami penurunan tekanan darah.

\subsubsection{Pengaruh relaksasi otot progresif terhadap penurunan tekanan darah pada lansia dengan hipertensi di Dusun IV Tanjung Anom Medan Tahun 2018}

Relaksasi otot progresifdalam penelitian ini, yang dilakukan pada 28 responden didapatkan adanya perubahan tekanan darah. Relaksasi ini dilakukan 3 kali selama 3 hari berturutturut dengan frekuensi $1 \mathrm{x}$ sehari durasi waktu 20-30 menit. Setelah dilakukan relaksasi otot progresif terhadap penuurunan tekanan darah pada lansia dengan hipertensi didapatkan adanya pengaruh signifikan dengan hasil 0,000 $(\mathrm{p}<0,05)$. Didapat dari 28 responden menunjukkan bahwa yang mengalami tekanan darah normal sebanyak $(10,7 \%)$, prehipertensi sebanyak $(46,4 \%)$, hipertensi tahap 1 sebanyak $(35,7 \%)$ dan hipertensi tahap 2 sebanyak $(7,2 \%)$.

Ayuningsih (2018), menyatakan bahwa pelaksanaan relaksasi otot progresif yang dilakukan pada usia $>45$ tahun selama 3 hari mengalami penurunan tekanan darah responden 1 penurunan $40 \mathrm{mmHg}$, responden $2,3,5$ penurunan $30 \mathrm{mmHg}$, dan responden 4 penurunan $50 \mathrm{mmHg}$, serta tidak mengalami pusing, pandangan tidak kabur, tidak ada pegal, tidak ada letih, tidak gelisah dan jantung tidak berdebardebar. Herawati (2016), menyatakan bahwa relaksasi akan memberikan rasa tenang yang membuat aksi baroreseptor beraksi di hipotalamus untuk mengurangi kadar kortisol, epinefrin dan noreprineprin yang dapat menyebabkan penurunan tekanan darah dan denyut nadi. Tingkat kortisol dalam darah mempengaruhi vasokontriksi pembuluh darah. Tekanan darah lansia setelah dilakukan relaksasi otot progresif (20\%) responden mengalami pre hipertensi. 
Penurunan kadar epinefrin dan noreprineprin bisa menyebabkan vasodilatasi pembuluh darah sehingga dapat menurunkan resistansi perifer total yang akan menurunkan tekanan darah.

Didukung oleh Dusek dan Benson ( 2009), hasil penelitian di dapatkan tekanan darah sistolik dan diastolik dapat menurun dengan latihan relaksasi otot progresif. Hal ini disebabkan oleh tekanan darah sistolik dipengaruhi oleh psikologis sehingga dengan relaksasi akan mendapat ketenagaan yang membuat baroreseptor mengeluarkaan aksi di hipotalamus untuk menurunkan kadar kortistol, epineprin yang dapat menyebabkan penurunan tekanan darah dan frekuensi nadi. Kadar koristol dalam darah berefek dalam vasokontriksi pembuluh darah. Penurunan kadar epineprin dan norepireprin dapat menyebabkan vasodilatasi pembuluh darah. Epineprin dan noepineprin ini dapat menurunkan perifer total yang akan menurunkan tekanan darah

Hasil penelitian ini sesuai dengan teori yang pertama kali dikembangkan oleh Edmund Jacobsen tahun 1938, yang percaya bahwa seseorang dapat diubah menjadi relaks pada otot-ototnya. Sekaligus juga latihan ini mengurangi reaksi emosi yang bergelora, baik pada sistem saraf pusat maupun pada sistem saraf otonom. Latihan ini dapat meningkatkan perasaan segar dan sehat. Teknik ini merupakan teknik yang lebih pendek, lebih sederhana dan lebih mudah untuk dilakukan (Gunarsa, 2008).

Hal ini juga didukung dengan teori Muttaqin (2014), relaksasi juga sangat penting bagi tubuh seseorang karena stimulasi peregangan di arkus aorta dan sinus karotis diterima dan diteruskan oleh saraf vagus ke medula oblongata (pusat regulasi kardiovaskuler), dan selanjutnya terjadinya peningkatan refleks baroreseptor. Impuls aferen dari baroreseptor mencapai pusat jantung yang akan merangsang saraf parasimpatis dan menghambat pusat simpatis, sehingga menjadi vasodilatasi sistemik, penurunan denyut dan kontraksi jantung. Perangsangan saraf parasimpatis ke bagian-bagian miokardium lainnya mengakibatkan penurunan kontraktilitas, volume sekuncup menghasilkan suatu efek inotropik negatif. Keadaan tersebut mengakibatkan penurunan volume sekuncup dan curah jantung. Pada otot rangka beberapa serabut vasomotor mengeluarkan asetilkolin yang menyebabkan dilatasi pembuluh darah dan akibatnya membuat tekanan darah menurun.

Ayunani (2014), menunjukkan bahwa ada penurunan dari hipertensi stadium 1 menjadi pre hipertensi. Dengan latihan yang benar dan didukung dengan teori bahwa melakukan latihan relaksasi otot progresif $7 \mathrm{x}$ selama 1 minggu secara teratur selama 20-30 menit mampu membantu lansia pada kondisi yang lebih relaks dan tenang sehingga dapat mempengaruhi tingkat stress sehingga dapat memicu aktivitas memompa jantung berkurang dan arteri mengalami pelebaran, sehingga banyak cairan yang keluar dari sirkulasi peredaran darah. Hal tersebut akan mengurangi beban kerja jantung karena penderita hipertensi mempunyai denyut jantung yang lebih cepat untuk memompa darah akibat dari peningkatan darah. Sehingga dari relaksasi otot progresif inilah yang menyebabkan terjadinya penurunan tekanan darah.

Didukung Inayatul (2017), yang menyatakan bahwa melakukan relaksasi otot progresif selama $7 \mathrm{x}$ dalam 1 minggu yang dilakukan 2 kali dalam sehari pagi dan sore dengan waktu 25-30 menit setiap sesinya akan mampu menurunkan tekanan darah yang lebih. Jika relaksasi otot progresif yang teratur dilakukan maka aksi hipotalamus akan 
menyesuaikan dan terjadi penurunan aktifitas sistem saraf simpatis sehingga dapat mengurangi ketegangan otot, menurunkan frekuensi jantung dan menurunkan tekanan darah.

Setelah dilakukan relaksasi otot progresif kepada lansia di Dusun IV Tanjung Anom Medan ditemukan pada 28 responden adanya perubahan penurunan tekananan darah pada lansia dengan usia $\geq 55$ tahun. Respon yang terlihat pada responden, yaitu responden lebih merasa rileks, tenang dan nyaman setelah melakukan relaksasi otot progresif tersebut. Dan responden juga mengalami pengurangan ketegangan pada otot-otot yang tegang. Penurunan tekanan darah ini terjadi karena dalam kondisi relaks, tubuh akan mengalami fase istirahat. Pada saat itulah, tubuh akan mengaktifkan sistem saraf parasimpatetis. Bekerjanya saraf parasimpatetis menyebabkan terjadinya penurunan detak jantung, laju pernafasan dan tekanan darah. Dalam penelitian ini peneliti menemukan responden yang mengalami tekanan darah hipertensi tahap 1 dan hipertensi tahap 2. Hal ini disebabkan karena keterbatasan waktu saat penelitian yang hanya dilakukan selama 3 kali 3 hari berturut-turut pada pagi hari selama 2030 menit kepada 28 responden. Dan selama penelitian ada beberapa responden yang tidak begitu serius dalam melakukan relaksasi otot progresif dan tidak terlalu merasakan relaksasi setelah melakukan keadaan tegang pada otot. Relaksasi otot progresif ini jika dilakukan dengan teratur dan serius akan dapat menurunkan peningkatan tekanan darah serta otot-otot yang tegang menjadi relaks.

\section{KESIMPULAN}

Hasil penelitian dengan jumlah sampel sebanyak 28 orang didapatkan adanya Pengaruh Reaksasi Otot Progresif Terhadap Penurunan Tekanan
Darah Pada Lansia Dengan Hipertensi Di Dusun IV Tanjung Anom Medan Tahun 2018. Secara keseluruhan dapat diuraikan sebaga berikut:

1. Tekanan darah responden pre intervensi pada lansia dengan hipertensi di Dusun IV Tanjung Anom Medan Tahun 2018 didapatkan sebagian besar pada hipertensi tahap 1 sebanyak 16 orang $(57,1 \%)$.

2. Tekanan darah responden post intervensi pada lansia dengan hipertensi di Dusun IV Tanjung Anom Medan Tahun 2018 didapatkan sebagian besar pada prehipertensi sebanyak 13 orang $(46,4 \%)$.

3. Terdapat Pengaruh Reaksasi Otot Progresif Terhadap Penurunan Tekanan Darah Pada Lansia Dengan Hipertensi Di Dusun IV Tanjung Anom Medan Tahun 2018 dengan hasil uji statistic wilcoxon sign rank test, diperoleh $p$ value $=$ $0,000(p<0,05)$.

\section{SARAN}

Hasil penelitian dengan jumlah responden sebanyak 28 orang mengenai Pengaruh Reaksasi Otot Progresif Terhadap Penurunan Tekanan Darah Pada Lansia Dengan Hipertensi Di Dusun IV Tanjung Anom Medan Tahun 2018 maka disarankan kepada:

1. Bagi Puskesmas Tanjung Anom Memberikan informasi kesehatan mengenai penanganan pencegahan tentang permasalahan yang berkaitan dengan tekanan darah lanjut usia serta menerapkan relaksasi otot progresif yang dapat menurunkan tekanan darah serta meningkatakan pelayanan bagi para lanjut usia agar senantiasa sehat dan bugar.

2. Bagi responden

Hasil penelitian ini diharapkan para lansia mampu menerapkan relaksasi otot progresif ini secara rutin setiap 
hari dan melakukannya dengan serius.

3. Bagi lingkungan STIKes Santa Elisabeth Medan

Hasil penelitian yang diperoleh dapat menambah informasi dan referensi yang berguna bagi mahasiswa/mahasiswi Sekolah Tinggi Ilmu Kesehatan Santa Elisabeth Medan tentang pengaruh relaksasi otot progresif terhadap penurunan tekanan darah pada lansia dengan hipertensi

4. Peneliti selanjutnya

Diharapkan peneliti selanjutnya dapat memberikan intervensi relaksasi otot progresif setiap hari dalam 2 kali sehari pagi dan sore secara teratur. Serta menggunakan kelompok pembanding (kontrol) agar mendapatkan hasil atau pengaruh yang signifikan.

\section{DAFTAR PUSTAKA}

Aspiani, Reny Yuli. (2014). Buku Ajar Asuhan Keperawatan Gerontik. Jakarta : TIM

Ayunani, Siti Akhati. (2014) Pengaruh Latihan Relaksasi Otot Progresif Terhadap Tekanan Darah Pada Lanjut Usia Dengan Hipertensi Di Upt Pslu Mojopahit Kabupaten Mojokerto , (online), (repository.umy.ac.id/bitstream/... Inaskah\%20publikasi.pdf?...y diakses 18 Desember 2017).

Dalimartha, Setiawan, dkk. (2008). Care Your Self Hipertensi. Jakarta: Penebar Plus

DepKesRI. (2006.) Pedoman Teknis penemuan an tatalaksana penyakit hipertensi. online (www.depkes.go.id/download.php ?file...hipertensi.pdf, diakses 8 Januari 2018)

Dusek dan Benson. (2006). Mind-Body Medicine: A Model of the Comparative Clinical Impact of the Acute Stress and Relaxation
Responses , (online), (https://www.ncbi.nlm.nih.gov/pm c/articles/PMC2724877/pdf/nihms 128719.pdf, diakses 17 April 2018)

Gunarsa, Singgih D. (2008). Psikologi Olahraga Prestasi. Jakarta: Gunung Mulia

Herawati, isnaini. (2016). Effect of progressive muscle relaxation Exercise to decrease blood pressure for Patients with primary hypertension, international conference on health and wellbeing, (online), (https://publikasiilmiah.ums.ac.id/ bitstream/handle/11617/7430/50 $\% 20-$ \%20Isnaini\%20Herawati.pdf?seq uence $=1$, diakses 28 Desember 2017)

Herwati dan Wiwi. (2011). Terkontrolnya tekanan darah penderita hipertensi

Berdasarkan pola diet dan kebiasaan olahraga Dipadang tahun 2011, jurnal kesehatan masyarakat, vol 8 no 1 (online), (jurnal.fkm.unand.ac.id/index.php /jkma/article/view/118/124, diakses 13 April 2018)

Kemenkes RI. (2014). Pusat Data dan Informasi Kementrian Kesehatan RI. Jakarta Selatan

Khairani, Lenny dan Eka. (2015). Pengaruh Relaksasi Otot Progresif Terhadap Penurunan Tekanan Darah Pada Lansia Penderita Hipertensi Di Yayasan Babus Salam Nurul Hikmah Tahun 2015.(online)(https://media.neliti. com/media/publications/187694ID-none.pdf, diakses 17 April 2018)

Kowalak, jenifer. (2011). Buku ajar patofisiologi. Jakarta:EGC

Maryam, R.Siti. (2008). Mengenal Usia Lanjut Usia dan Perawatannya. Jakarta: Salemba Medika 
Mckay, Gary .(2005). How You Feel Is Up To You. Jakarta: Grasindo

Mubarak, dkk. (2015). Buku Ajar Ilmu Keperawatan Dasar Buku 2. Jakarta : Salemba Medika

Muttaqin, Arif. (2014). Buku ajar asuhan keperawatan klien dengan gangguan sistem kardiovskular dan hematologi. Jakarta: EGC.

Notoadmojo. (2012). Metodologi Penelitian Kesehatan. Jakarta : Rineka Cipta.

Nugroho. (2012). Keperawatan Gerontik Dan Geriatik. Jakarta: EGC.

Nursalam. (2016). Manajemen Keperawatan: Aplikasi dalam Prkatik Keperawatan Profesional. Jakarta : Salemba Medika.

Padila. (2013). Buku Ajar Keperawatan Gerontik. Yogyakarta: Nuha Medika.

Polit, Denise F dan Beck, Cheryl Tatano. (2012). Nursing Research: Generating and Assessing Evidence Nursing Practice. Philadelphia: Lippincot Williams \& Wilkins

Potter, Patricia. (2005). Buku Ajar Fundamental Keperawatan : Konsep, Proses, dan Praktik. Jakarta : EGC.

Racmaht ,Mochamad. (2012). Buku Ajar Biostatistika Aplikasi pada Penelitian Kesehatan. Jakarta: EGC

Santoso, dkk. (2009). Memahami Lanjut Usia. Jakarta: Gunung Mulia

Setyoadi, Kushariyadi. (2011). Terapi Modalitas Keperawatan Pada Klien Psikkogeriatrik. Jakarta : Salemba Medika

Sugiyono. (2016). Metode Penelitian Kuantitatif, Kualitatif dan $R \& D$. Bandung: ALFABETA.

Tjokroprawiro, dkk. (2015). Buku ajar Ilmu Penyakit Dalam. Surabaya: Airlangga University Press.
Tyani, Endar Sulis. (2015). Efektifitas Relaksasi Otot Progresif Terhadap Tekanan Darah Pada Penderita Hipertensi Esensial, jom vol. 2 no. 2 , (online), (https://media.neliti.com/media/pu blications/187694-ID-none.pdf , diakses 4 Januari 2018).

Wilkins \& Wiliams, Lippincott. (2014). Kapita Selekta Penyakit. Jakarta : EGC 